\title{
Spatial Variability of Sediment Yield in Turkish Basins
}

\author{
Omer Levend Asikoglu*, Ebru Eris \\ Ege University, Civil Engineering Department, Bornova, Izmir, Turkey
}

Received: 16 March 2018

Accepted: 7 May 2018

\begin{abstract}
It is of great importance to know the amount of sediment transported to water structures and/or irrigation facilities during their planned lifetime. The amount of sediment transported is used in the design of such facilities, thus minimizing sedimentation losses. Determining sediment amount is generally based on empirical and physical modeling and on the relationship between sediment load and stream flow, where the sediment concentration measurements are correlated with flow characteristics. Each of these methods has some weaknesses. This study aimed to prepare a sediment yield map using suspended sediment measurements obtained from the State Hydraulic Works in 114 observation stations with a recording length of 15 years or more. Since the relationship between the amount of sediment and flow rate is known, the flow rate is considered as secondary data and sediment yield is mapped by the co-kriging method. The map showing spatial variation of the sediment yield was evaluated with the calibration and validation stages, and satisfactory results were obtained. Thus, sediment yield can be estimated at a project site where there is no suspended sediment measurement.
\end{abstract}

Keywords: suspended sediment yield, sediment yield map, co-kriging

\section{Introduction}

Sediment yield is defined as the amount of sediment measured at a reference point for a given time period and is given in tons/year or tons $/$ year $/ \mathrm{km}^{2}$ related to the area [1]. Generally, sediment yield estimations are needed as part of the feasibility study of a planned dam or water structure, and the annual average sediment yield is considered to be sufficient.

Modeling studies aiming to determine sediment yield are examined in four main groups in general [2]:

*e-mail: omer.asikoglu@ege.edu.tr

- Empirical models in which sediment yield equations are derived from known basin and climatic characteristics.

- Soil erosion and sediment yield approaches in which measured or estimated soil erosion rates are often multiplied by a sediment distribution rate based on basin characteristics.

- Physically based or physically distributed basin modelling approaches in which the movement of water and soil is estimated in a distributed way throughout the basin.

- Models that relate to sediment concentration or sediment load to stream flow in which the sediment concentration measurements are correlated with flow characteristics. 
Calculating sediment yield has been the subject of many studies in the literature [1, 3-29], many of which are based on the above-mentioned modeling principles.

In the studies carried out, in some cases it is observed that the sediment yield estimates have been exceeded before dam construction starts. An important reason why reasonable estimates for average annual sediment yield cannot be achieved is that the relationships derived from field data are applied without considering the suitability for future conditions. The effects of changes in land use on sediment yield have been extensively addressed in the literature [30, 31]. Similarly, climate and flow variability also cause changes in sediment accumulation or yield $[32,33]$. An important factor in sediment yield estimates is the sediment concentrationwater discharge relationships, which are based on low-density data. The non-linear and non-stationary structures in these relationships cause their use to be at high risk. The sediment transport capacity also varies according to climatic variables and operating conditions of the land considered as a source of sediment. Recent studies, however, have shown that river basin conditions and erosion play an important role in sediment transport, and in some cases are more important than other sediment sources. These sources are rarely able to move and materials collected from the rivers may have been previously accumulated by the river system. For this reason, the time interval considered in the sediment yield estimates should be wide. The relationship between river morphology and sediment yield is not generally considered in the sediment yield model, but it can be a basis for making better predictions. Another difficulty of modeling is the precise definition of the shape, size, and density of sediment. In general, this variability is defined with the soil type of the basin remaining at the upstream of a measurement point, but the activities performed by humans may change the structure of the particle and/or the size of the size range of the sediment carried. For example, when forests are destroyed, pasture fields are plowed, mine waste is disposed of, or concrete is poured for a new urban area, and the transport balance of nature and the ratio of different sediment particles that can be transported changes.

The process of natural complexity, spatial heterogeneity, and lack of available data, coupled with the challenges listed above, makes it almost impossible to develop a model with reasonable results - especially for basins larger than $30 \mathrm{~km}^{2}$ [34].

In addition to the modeling studies mentioned above, sediment yield maps are used to show the regional variability of sediment sources in a drainage basin and the temporal changes in the relative contributions of various parts of the basin. There are a number of studies to obtain maps of global and regional scale sediment yields [35-37].

In this study, "sediment yield maps" were obtained using sediment data observed in 114 basins of Turkey. With the help of this map showing the spatial variation of the sediment yield, the above-mentioned modeling difficulties will be avoided and reliable information about sediment yield will be achieved even at a project point where there is no measurement.

\section{Data}

A sediment yield map was prepared using the long-term average values of a suspended sediment monitoring station in Turkish river basins. Data were collected from 114 observation stations with a measurement year of 15 years or more. The oldest observations are from 1961 and the latest observation year is 2012. Data observation period varies between 15 and 52 years. The average annual flow, which is the secondary data used in the mapping, is obtained from the State Hydraulic Works (DSI with Turkish acronym) [38]. Annual mean of sediment yield and flow is 123 ton $/$ year $/ \mathrm{km}^{2}$ and $55.3 \mathrm{~m}^{3} / \mathrm{s}$, respectively. Locations of the observation stations are shown in Fig. 1.

For validating the method, sediment yield data of 15 stations (ranging from 10- to 15-year recording periods) were used. Such observation stations are also given in Fig. 1.

\section{Methods}

Kriging is one of the most commonly used geostatistical methods and was originally developed for geoscience applications. Recently, it has been frequently used for mapping various hydrological parameters. $\mathrm{n}$ this study, kriging is used to map the sediment yield.

The method is based on the principle of calculating unknown points from known measurement points with the help of a semi-variogram. If the sample points $x_{1}, x_{2}, \ldots, x_{n}$, and the yield values at these points $Z\left(x_{1}\right), Z\left(x_{2}\right), \ldots, Z\left(x_{n}\right)$, and $Z\left(x_{o}\right)$ are considered to be the desired yield value, $Z\left(x_{0}\right)$ value can be defined as a weighted combination of $n$ known yield values located around it (Equation 1):

$$
Z^{*}\left(x_{o}\right)=\sum_{i=1}^{n} \lambda_{i} Z\left(x_{i}\right)
$$

...where $\lambda_{i}$ represent weights, $Z^{*}\left(x_{0}\right)$ represents the unbiased state of the $Z^{*}\left(x_{o}\right)$ value, and the expected value of this difference must be zero. Likewise, the expected value of the estimated variance is the minimum.

Determining the most suitable weights is achieved by solving the linear system given in Equation 2, which is called kriging:

$$
\sum_{i=1}^{n} \lambda_{i} \gamma\left(x_{i}, x_{j}\right)+\mu=\gamma\left(x_{i}, x_{j}\right) \sum_{;}^{n} \lambda_{i}=1
$$




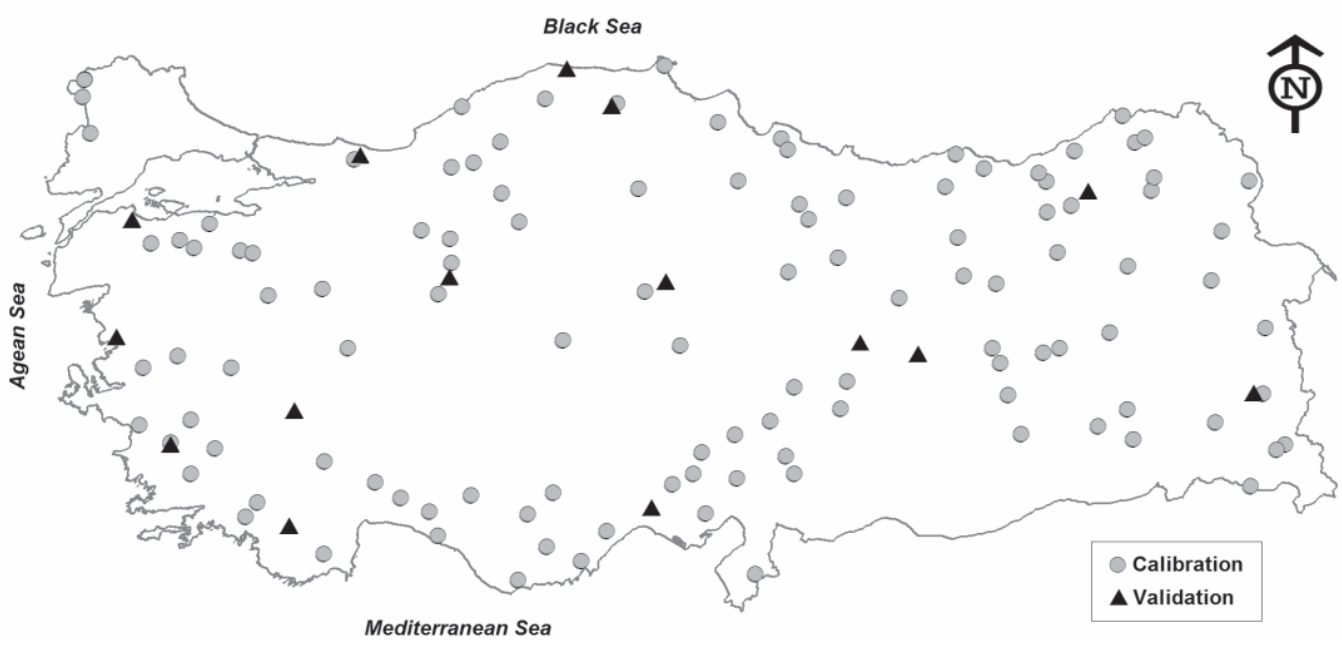

Fig. 1. Locations of observation stations used in the study.

...where $\gamma(h)$ is a semi-variogram and $\mu$ is Lagrange factor. The semi-variogram $\gamma(h)$ is defined as:

$$
\gamma(h)=\frac{1}{2} \operatorname{var}(Z(x+h)-Z(x)
$$

...where $h$ represents the distance between two observation points (lag) and var () represents variance. In summary, in order to find the appropriate weights in kriging, the location dependence of the observations must be known. Location dependency can be defined either by using a covariance function or a variogram function.

Variogram is a function that characterizes the dependence between variables located in different points in space. Kriging weights are a direct function of the variogram model. If kriging is used as an interpolation technique for a study area, then the parameters of the selected variogram model should be known, in other words, the experimental variogram model should be generated using the data in the study area. By using an experimental variogram, unknown parameters of the theoretical model should be determined [39]. There are different theoretical models that have been proposed to fit on an experimental variogram such as linear, exponential, spherical, and Gaussian. After calculating the semi-variograms for certain distances, $\lambda_{i}$ weights are calculated and the yield value of the unknown point is found.

Different kriging techniques such as simple, ordinary kriging, universal kriging, and co-kriging are widely used. In ordinary kriging, the average of the variable is unknown, whereas in simple kriging the solution is based on the assumption that the average is known and constant. If data has a trend and trend is taken into account, universal kriging can be used. The co-kriging method is an extension of ordinary kriging and interpolates considering the spatial correlation between two or more variables.
The co-kriging estimate is a linear combination of both primary and secondary data values as given by Equation 4:

$$
Z^{*}\left(x_{o}\right)=\sum_{i=1}^{n} \lambda_{i} Z\left(x_{i}\right)+\sum_{j=1}^{n} \beta_{j} Z\left(x_{j}\right)
$$

Primary data is sediment yield whereas secondary represents flow data in this case. The development of the co-kriging system is identical to the development of the ordinary kriging system.

\section{Application and Results}

In this study the co-kriging method is used based on the spatial relationship between flow and sediment yield. Since the kriging method is based on Gaussian statistics, it assumes the normality of the data used. If distribution of the data is highly skewed, several transformations such as logarithmic transformation provide normality [40]. Note that non-normal distributed data increases prediction error.

As seen from Q-Q graphs given in Fig. 2, logarithmic transformation normalizes the distribution of the data.

Spatial distribution of the flow and sediment yield data is shown in Fig. 3. In case any trend is observed, the best model (linear, exponential, global, Gaussian, etc.) must be fitted to the variogram of the remains obtained by subtracting the observed trend from original data. However, as can be seen from Fig. 3, there is no clear trend in north-south or east-west direction for both sediment yield and flow. For this reason, the trend is not taken into consideration in this study.

For sediment yield map generation, most commonly used theoretical models (linear, exponential, spherical, Gaussian, and circular) that can best represent the experimental variogram are chosen. Fig. 4 shows root mean square errors (RMSEs) obtained from cross- 

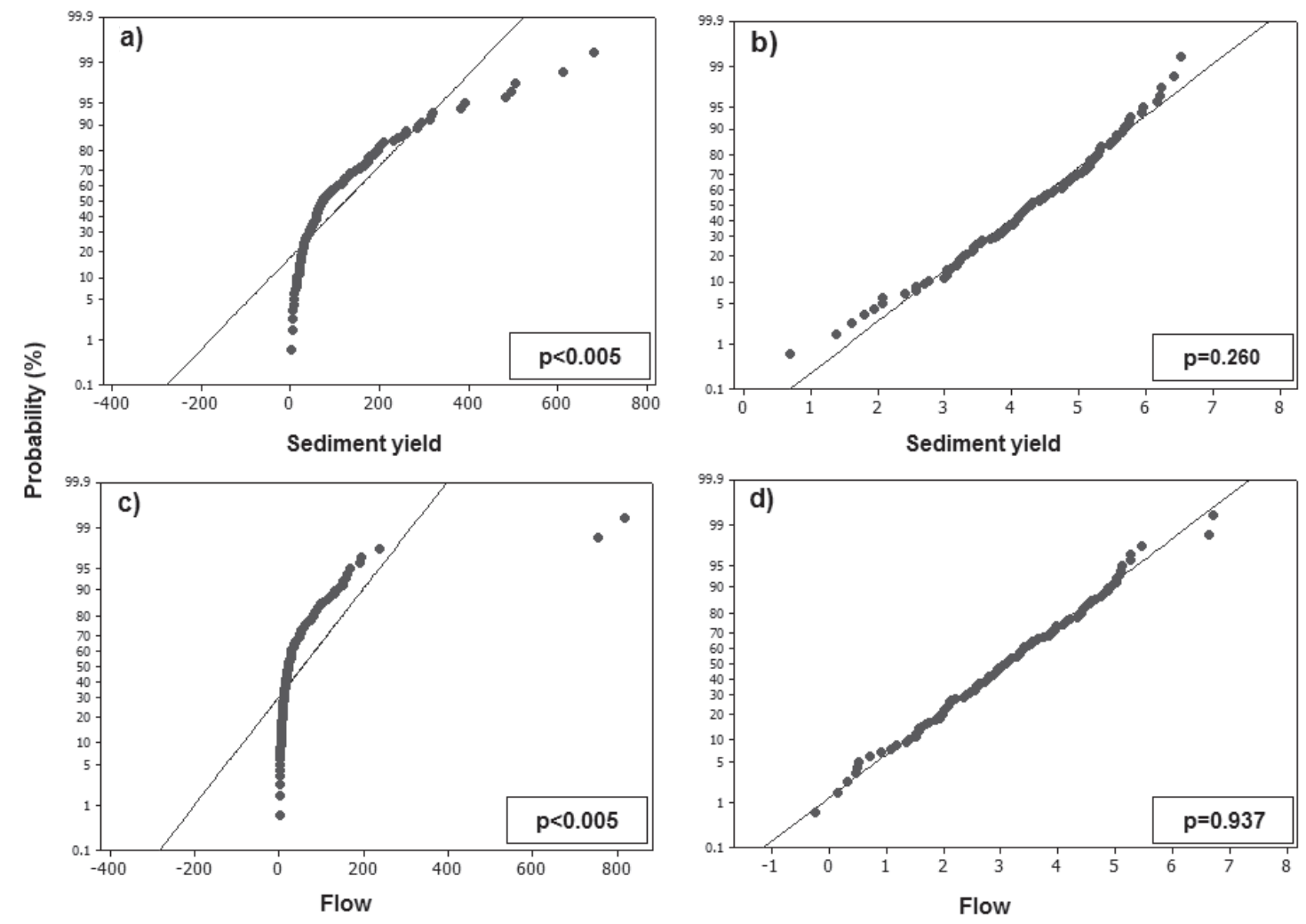

Fig. 2. Q-Q graphs: sediment yield a) original data, b) logarithmic transformed data, flow c) original data, and d) logarithmic transformed data.

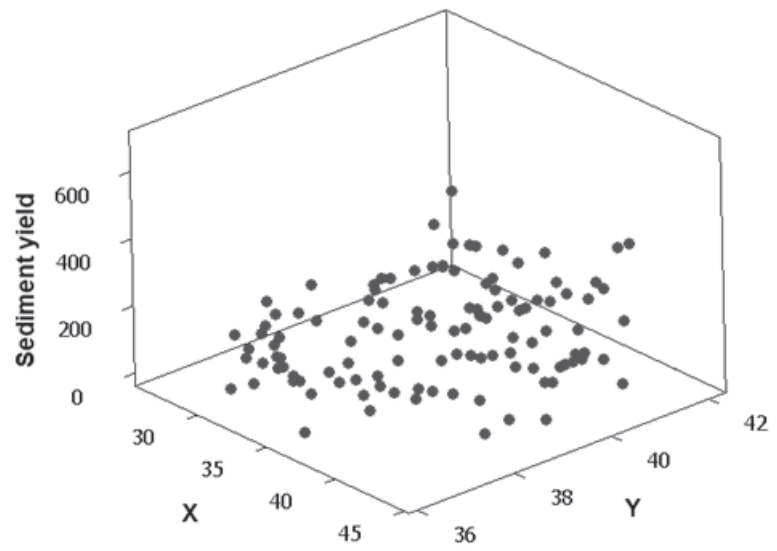

validation results based on the number of neighbors used in the estimation for each theoretical model. With the number of 15 neighbor points, the exponential model that has the lowest RMSE value was found as the most appropriate model for sediment yield.

A sediment yield map generated using the exponential model with the number of 15 neighbors is given in Fig. 5. The validation of the map is performed using 15 observation points that were not used during

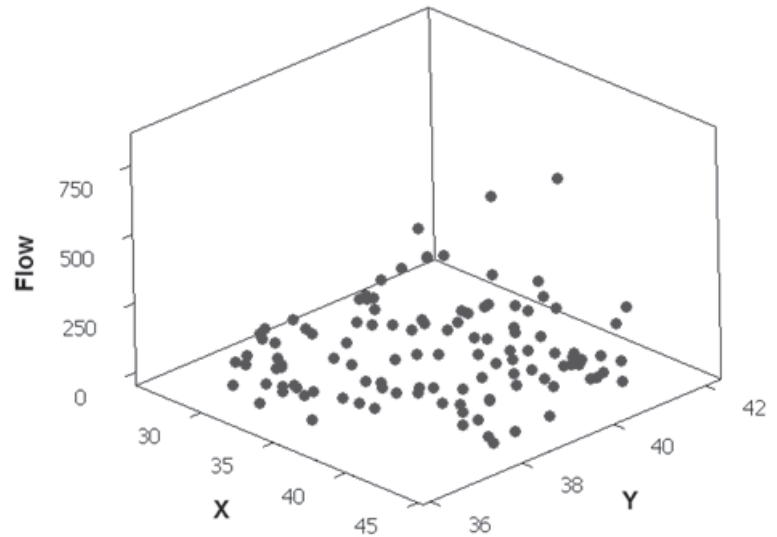

Fig. 3. Spatial distributions of original data.

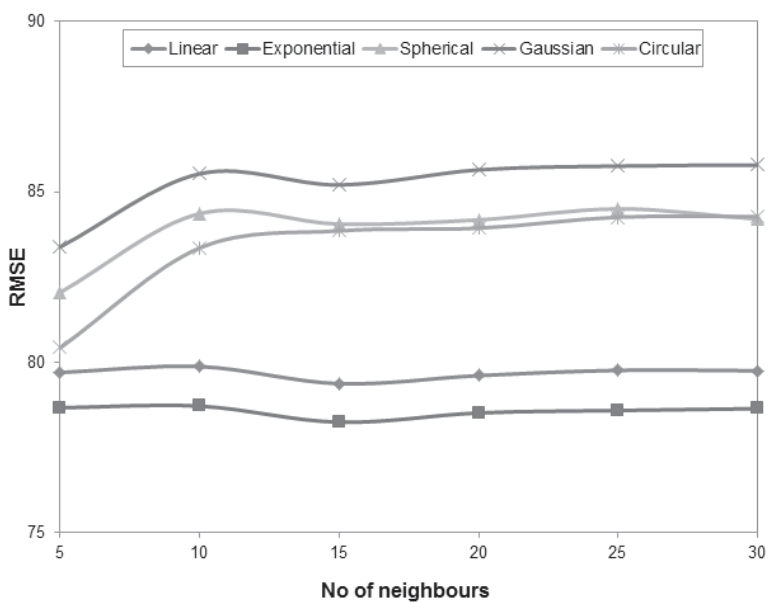

Fig. 4. RMSEs for the theoretical variogram models with the number of neighbors. 


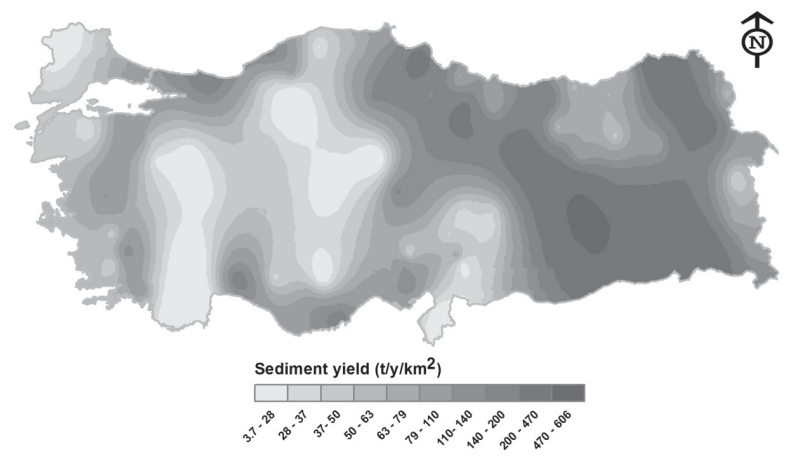

Fig. 5. Sediment yield map.

the calibration stage. Fig. 6 shows the scatter diagram of the observations and estimations obtained from the generated map of the 15 validation points. Accordingly, the correlation coefficient of the validation is found to be approximately 0.85 . As can be understood from the scatter diagram, the sediment yield in the country is quite variable; the sediment yield data of 114 stations used in the study varies between approximately 2 and 681 ton $/$ year $/ \mathrm{km}^{2}$. This makes it difficult to estimate the suspended sediment yield and increases the number of variables/parameters to be included in the methods. On the other hand, since the sediment carried in the rivers is $50-95 \%$ of suspended type [41], it is important to determine suspended sediment yield properly. For this reason, it is more suitable to use long-term measurements instead of analytical methods in predicting the sediment amount [42].

Although various empirical methods have been used for calculating basin-based sediment yield in Turkey, these methods have very different results [13].

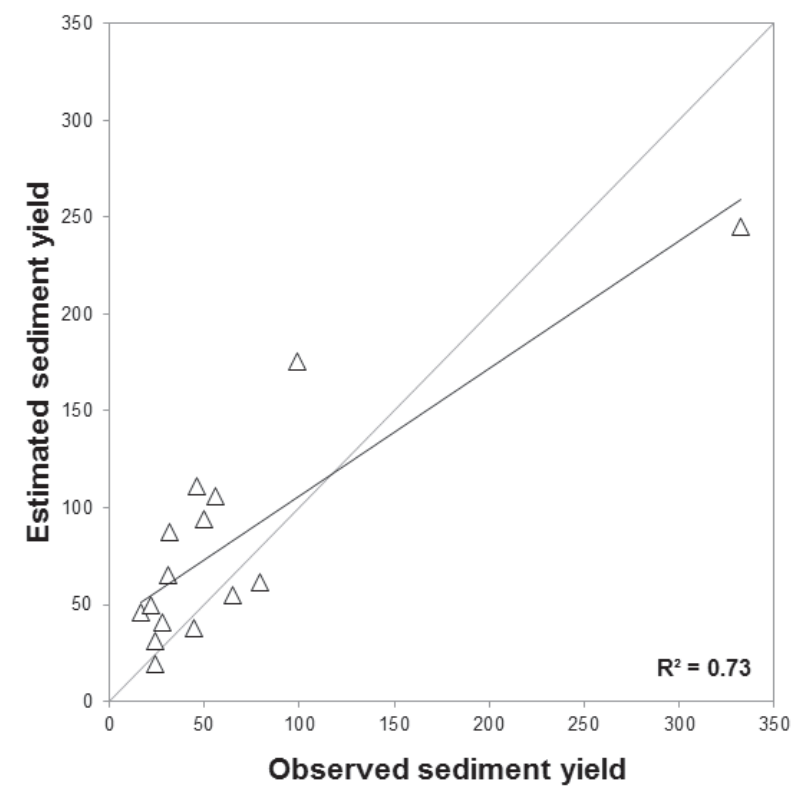

Fig. 6. Observed-estimated scatter diagram for sediment yield (validation).
Using a generated sediment yield map, the most accurate sediment yield at any point where no observation is available will be provided in a short time.

\section{Conclusion}

As a consequence of sediment transport carried by rivers, the economic life of storage facilities such as dams is shortened; flood prevention, hydropower generation, irrigation, drinking water supply, and recreation are adversely affected and additional costs are incurred. In this respect, accurate estimation of the sediment amount is of great importance.

Since many factors such as geological, topographical, and climatological factors are influential on the amount of sediment, empirical methods may produce quite different results. For this reason, it is more realistic to use estimates based on measurements instead of empirical methods. Generating sediment maps using observed data, for example, would allow for the elimination of such inconsistencies.

Also, in Turkey such empirical methods have been widely used for calculating basin-based sediment yield producing similar inconsistent results. Besides, nationally based studies have not included the spatial variation of sediment yield.

Therefore, in this study a sediment yield map was prepared using the long-term average values of suspended sediments collected from 114 observation stations in Turkish river basins.

The result of the study is compared with global sediment yield maps [36, 43]. These maps show global distribution of sediment yield on the basis of field data. There is good agreement between these maps and the map of this study. In addition, it contains more detailed information since it is generated on a smaller scale.

This map allows the user to provide practical sediment yield estimation at a point where there is no sediment measurement.

\section{Conflict of Interest}

The authors declare no conflict of interest.

\section{References}

1. VERSTRAETEN G., POESEN J. Factors controlling sediment yield from small intensively cultivated catchments in a temperate humid climate. Geomorphology 40, 123, 2001.

2. WUTTICHAIKITCHAROEN P., BABEL M.S. Principal Component and Multiple Regression Analyses for the Estimation of Suspended Sediment Yield in Ungauged Basins of Northern Thailand. Water, 6, 2412, 2014.

3. MEDEIROS P.H.A., GUNTNER A., FRANCKE T., MAMEDE G.L., de ARAUJO J.C. Modelling spatiotemporal patterns of sediment yield and connectivity 
in a semi-arid catchment with the WASA-SED model. Hydrol. Sci. J., 55, 636, 2010.

4. KUSVURAN K. Investigation of Rainfall and Flow in Mersin - Tarsus Topcu Deresi Basin and Sediment Yield in Lower Basin. General Directorate of Agricultural Research Tarsus Research Institute of Soil and Water Resources, Project Nr: TAGEM-BB-TOPRAKSU-2011/125, 2011.

5. AREKHI S., SHABANI A., ALAVIPANAH S.K. Evaluation of Integrated KW-GIUH and MUSLE Models to Predict Sediment Yield Using Geographic Information System Case Study: Kengir Watershed, Iran. African Journal of Agricultural Research, 6 (18), 4185, 2011.

6. BENJAMIN H., MACKEY B.H., ROERING J.J. Sediment yield, spatial characteristics, and the long-term evolution of active earthflows determined from airborne LiDAR and historical aerial photographs, Eel River, California. GSA Bulletin, 123 (7-8), 1560, 2011.

7. DYSARZ T., WICHER-DYSARZ J. Application of Hydrodynamic Simulation and Frequency Analysis for Assessment of Sediment Deposition and Vegetation Impacts on Floodplain Inundation. Pol. J. Environ. Stud. 20 (6), 1441, 2011.

8. MAYOR Á.G., BAUTISTA S., BELLOT J. Scaledependent variation in runoff and sediment yield in a semiarid Mediterranean catchment. Journal of Hydrology. 397 (1-2), 128, 2011.

9. NADAL-ROMERO E., MARTÍNEZ-MURILLO J.F., VANMAERCKE M., POESEN J. Scale-dependency of sediment yield from badland areas in Mediterranean environments. Progress in Physical Geography, 35 (3), 297, 2011.

10. TUNNICLIFFE J, CHURCH M. Scale variation of postglacial sediment yield in Chilliwack Valley, British Columbia. Earth Surface Processes and Landforms, 36, 229, 2011.

11. VANMAERCKE M., POESEN J., VERSTRAETEN G., de VENTE J., OCAKOGLU F. Sediment yield in Europe: spatial patterns and scale dependency. Geomorphology, 130, 142, 2011.

12. VANMAERCKE M., POESEN J., MAETENS W., de VENTE J., VERSTRAETEN G. Sediment Yield as a Desertification Indicator. Science of the Total Environment, 409, 1715, 2011.

13. AKSU, N., UCAN, K. Comparison of observed sediment yields with the sediment yields calculated by empirical methods in Hurman Creek basin. KSU Journal of Natural Sciences, 15 (3), 1, 2012.

14. PELLETIER J.D. A spatially distributed model for the long-term suspended sediment discharge and delivery ratio of drainage basins. Journal of Geophysical Research Earth Surface 117 F02028. 2012.

15. VIGIAK O, BORSELLI L, NEWHAM LTH, McINNES J, ROBERTS A.M. Comparison of conceptual landscape metrics to define hillslope-scale sediment delivery ratio. Geomorphology, 138, 74, 2012.

16. BUSSI G., RODRIGUEZ-LLOVERAS X., FRANCES F., BENITO G., SANCHEZ-MOYA Y., SOPENA A. Sediment yield model implementation based on check dam infill stratigraphy in a semiarid Mediterranean catchment. Hydrol. Earth Syst. Sci., 17, 3339, 2013.

17. RODRÍGUEZ-BLANCO M.L., TABOADA-CASTRO M.M., TABOADA-CASTRO M.T. Linking the field to the stream: soil erosion and sediment yield in a rural catchment, NW Spain Catena, 102, 74, 2013.

18. de VENTE J., POESEN J., VERSTRAETEN G., GOVERS G., VANMAERCKE M., VAN ROMPAEY
A., ARABKHEDRI M., BOIX-FAYOS C. Predicting soil erosion and sediment yield at regional scales: where do we stand? Earth-Science Reviews, 127, 16, 2013.

19. KOC G. Evaluation of erosion potential in Tarsus (Mersin) - Topcu Deresi lower basin using modified universal soil loss equation (MUSLE). Hacettepe University MSc Thesis in Department of Geological Engineering, Ankara, Turkey, 2014.

20. WORRALL F., BURT T.P., HOWDEN N.J.K., HANCOCK G.R. Variation in suspended sediment yield across the UK - a failure of the concept and interpretation of the sediment delivery ratio. Journal of Hydrology, 519, 1985, 2014.

21. BRACKEN LJ, TURNBULL L, WAINWRIGHT J, BOGAART P. Sediment connectivity: a framework for understanding sediment transfer at multiple scales. Earth Surface Processes and Landforms, 40, 177, 2015.

22. YESUF H.M., ASSEN M., ALAMIREW T., MELESSE A.M. Modeling of sediment yield in Maybar gauged watershed using SWAT, northeast Ethiopia. Catena, 127, 191, 2015.

23. ZHAO G., KONDOLF G.M., MU X., HAN M., HE Z., RUBIN Z., WANG F., GAO P., SUN W. Sediment yield reduction associated with land use changes and check dams in a catchment of the Loess Plateau, China. Catena, 148 (2), 126, 2017.

24. BUENDIA C., HERRERO A., SABATER S., BATALLA R.J. An appraisal of the sediment yield in western Mediterranean river basins. Science of the Total Environment, 572, 538, 2016.

25. RENS J. H. MASSELINK R.J.H., KEESSTRA S.D., TEMME A.J.A.M., SEEGER M., GIMÉNEZ R., CASALÍ J. Modelling Discharge and Sediment Yield at Catchment Scale Using Connectivity Components, Land Degradation and Development, 27 (4), 933, 2016.

26. SUN J. Ground Sediment Transport Model and Numerical Simulation. Pol. J. Environ. Stud, 25 (4), 1691, 2016.

27. CHURCH M. Interpreting sediment yield scaling. Earth Surface Processes and Landforms, 42 (12), 1895, 2017.

28. OZALP M., ERDOGAN YUKSEL E., YILDIRIMER S. Subdividing large mountainous watersheds into smaller hydrological units to predict soil loss and sediment yield using the GeoWEPP model. Pol. J. Environ. Stud., 26 (5), 2135, 2017.

29. ZHAO G., KLIK A., MU X., WANG F., GAO P., SUN W. Sediment yield estimation in a small watershed on the northern Loess Plateau, China. Geomorphology, 241 (15), 343, 2015.

30. GARCIA-RUIZ J.M., LASANTA T., MARTI C., GONZALEZ C., WHITE S.M., ORTIGOSA L., RUIZ FLANO P. Changes in runoff and erosion as a consequence of land-use changes in the central Spanish Pyrenees. Physics and Chemistry of the Earth, 20, 301, 1995.

31. LU X.X., HIGGITT D.L. Recent changes in sediment yield in the Upper Yangtze, China. Environmental Management, 22, 697, 1998.

32. BATHURST J.C., KILSBY C.G., WHITE,S.M. Modelling the impacts of climate and land use change on basin hydrology and soil erosion in Mediterranean Europe. Mediterranean Desertification and Land Use, Thornes J.B., Brandt C.J. (eds). Wiley: 355, 1996.

33. VALERO-GARC'ES B.L., NAVAS A., MACHIN J., WALLING D. Sediment sources and siltation in mountain reservoirs: a case study from the central Spanish Pyrenees. Geomorphology, 28, 23, 1999.

34. WASSON R.J. What approach to the modelling of catchment scale erosion and sediment transport should 
be adopted?, In: Modelling Erosion, Sediment Transport and Sediment Yield. IHP-VI Technical Documents in Hydrology, Summer, W., Walling, D.E. (Eds.), UNESCO, Paris, France, 1, 2002.

35. STONE M., SAUNDERSON H.C. Regional patterns of sediment yield in the Laurentian Great Lakes basin", In: Erosion and Sediment Yield, Global and Regional Perspectives (Proceedings of the Exeter Symposium, July 1996), Walling, D.E., Webb, B.W. (Eds.), IAHS Publ. 236, 125, 1996.

36. JANSSON M.B. A Global Survey of Sediment Yield. Geografiska Annaler. Series A, Physical Geography, 70 $(1 / 2), 81,1988$.

37. LU X.X., ASHMORE P., WANG J. Sediment yield mapping in a large river basin: the Upper Yangtze. China Environmental Modelling \& Software, 18, 339, 2003.
38. DSI. Sediment yield data. State Hydraulic Works, Turkey, 2013.

39. INAL C., YIGIT C.O. Usability of kriging interpolation method in geodetic applications. Scientific Meeting of 2003 Geographic Information Systems and Geodetic Networks. 24-26 September, Konya, Turkey, 2003.

40. KRAEHMER H. (Ed.) Atlas of Weed Mapping, John Wiley \& Sons. 488, 2016.

41. YANMAZ M. Applied Water Resources Engineering", METU Press. Ankara, Turkey, 1997.

42. MILLER C.B. Analysis of flow-duration, sedimentrating curve method of computing sediment yield. U.S. Department of Interior, Bureau of Reclamation Sedimentation, Denver, Colorado, 1951.

43. LUDWIG W., PROBST J.L. River sediment discharge to the oceans: present-day controls and global budgets. American Journal of Science, 298, 265, 1998. 
